\title{
An approach for the evaluation of efficiency of onion packinghouse operations
}

\author{
Andrés F.Lopes Camelo; Sandra Horvitz; Perla A. Gómez \\ INTA E.E.A. Balcarce CC 276, 7620 Balcarce, Argentina; Phone: 54 (2266) 439100, Fax: 54 (2266) 439101, E-mail: \\ lopezca@balcarce.inta.gov.ar
}

\begin{abstract}
The onion is a major export crop in Argentina and obtaining consistent quality is a matter of concern to remain competitive internationally. Grading is generally done according to Mercosur standards but quality assurance programs are necessary at the packinghouse level. The objective of this study was to develop a first approach for characterizing sorting and sizing efficiency. During the 1998 season five onion packinghouses located in the Valle Bonaerense del Río Colorado (Buenos Aires Province, Argentina) were randomly selected. In all of them, variables measured were: sorting table width, bulb transport and rotation speed as well as number of bulbs/sorter/hour. Before and after sorting, samples of 100 bulbs of each size category were randomly taken and closely inspected and their diameters were measured. Sizing efficiency was determined and a Chi-square test was performed to compare observed frequencies of defects with the expected ones within each category. All the studied packinghouses failed to meet the established limits for slight defects and only one of them was able to comply with the standards for basic requirements when preparing Extra class onions. Even when equipment and operational setup were different among packinghouses, the operational flux (bulbs/sorter/hour) was similar for all of them. Differences in sorting performance can be attributed mainly to the sequence of operations and speed of belt conveyors. Equipment and its calibration affected sizing efficiency, with better results obtained with the diverging roller system. The proposed methodology for characterizing efficiency could be considered as a simple and useful tool for monitoring quality at onion packinghouses.
\end{abstract}

Keywords: Allium cepa, packhouse, sorting, quality, postharvest.

\section{RESUMO}

Avaliação da eficiência das operações de classificação e embalagem de cebola

A cebola é o principal produto de exportação da Argentina e a obtenção de alta qualidade é importante para manter a competitividade em nível internacional. A classificação é feita geralmente de acordo com as normas do Mercosul, porém programas de controle de qualidade são necessários em nível de beneficiamento. O objetivo deste trabalho foi desenvolver um método para caracterizar a eficiência da tipificação e da classificação por tamanho. Durante a safra de 1998 cinco locais de beneficiamento do Vale Bonaerense do Rio Colorado (Província de Buenos Aires, Argentina) foram escolhidos ao acaso. Em todos eles, as variáveis medidas foram a largura da mesa de classificação, as velocidades de deslocamento e de rotação dos bulbos e também o número de bulbos/operário/hora. Antes e depois da classificação, amostras de 100 bulbos de cada tamanho foram escolhidas ao acaso, avaliadas e medidos seus diâmetros. A eficiência de classificação por tamanho foi determinada e o teste Qui-quadrado foi aplicado para comparar a frequiência de defeitos observada com aquela esperada dentro de cada categoria. Todas as packinghouses falharam em atingir os limites de defeitos preestabelecidos e somente uma delas atingiu as normas básicas da categoria classe Extra. Ainda, quando os equipamentos e o esquema operacional foram diferentes entre os locais de beneficiamento, o fluxo operacional (bulbos/operário/hora) foi similar entre eles. Diferenças na performance de classificação podem ser atribuídas principalmente à sequiência de operações e à velocidade das correias de transporte. $\mathrm{O}$ equipamento e sua calibração afetou a classificação por tamanho, com os melhores resultados obtidos com o sistema de rolos divergentes. A metodologia proposta para caracterizar a eficiência pode ser considerada como uma ferramenta simples e útil para monitorar a qualidade das packinghouses de cebola.

Palavras-chave: Allium cepa, beneficiamento, clasificação, qualidade, pós colheita.

\section{(Recebido para publicação em 22 de agosto de 2001 e aceito em 13 de setembro de 2002)}

$\mathrm{O}^{\mathrm{n}}$ nion is one of the most important vegetable crops in Argentina (24,570 ha in 1999) for domestic and for the foreign markets which makes up $40 \%$ of total production (SAGPyA, 1999). Exports are expanding and are worth about 80 million USD per year. They are mainly of cultivar Valcatorce INTA, a medium sized, relatively mild, long day, globe-type onion with a copper-brown external color.

In Argentina, onions are graded into three categories or quality classes, according to Mercosur standards (IASCAV, 1995), sharing a common but not always identical base with those for Europe and other markets. Bulbs must meet certain basic requirements, and grades only differ in the tolerances for slight and severe defects. Basic requirements are uniformity and the absence of serious damage (from biological or other sources), badly misshapen bulbs, soil, over or underweight sacks, chemical contamination, etc. Within the 'slight' defects category some damage is allowed as well as staining, incomplete closure of necks, and loss of skin or turgidity. Doubles are permitted if they are not deformed. Severe defects include rot, sprouting and/or rooting and bolted bulbs. Size categories have been specified for the Mercosur area (35-50; 50-70; 70-90 and >90 $\mathrm{mm}$ in diameter), although this is mainly a matter of buyer/ importer preference. 
Attaining and maintaining consistent quality has become a matter of concern for onion exporters and quality assurance schemes need to be established at the packinghouse level to guarantee a comparable quality for all shipments. Additionally, consumers perceive a more uniform product as of superior quality (Lidror \& Prussia, 1990). Our experience (López Camelo et al., 1998) indicates the feasibility of a postharvest Total Quality Management (TQM) approach fully integrated with the production system.

In Argentina, there are two packinghouse operation systems: sizing preceding sorting and vice versa. The first one usually consists of an automatic sizer (diverging plain rollers) with side delivering belts feeding three or more inspection tables where sorters perform a reduction sorting (Peleg, 1985) to separate into export quality (main flow), domestic market ( $2^{\text {nd }}$ quality) and culls (disposal). The same grades are obtained when sorting precedes sizing. In this case, fewer personnel and less space are required because equipment is usually more compact. Diverging-belts, belts and rollers or belts and boards are used as sizing systems.

Packinghouse efficiency has been defined in different ways: in some cases it is expressed in terms of the amount of packed product of a given quality per unit of time. More frequently, however, it is expressed as a synonym for sorting accuracy, indicating the ability of sorters to remove defective units, related or not to the total flow of product (Prussia, 1985; Lidror, 1989). Both definitions overlook the importance of sizing as the part of the operations yielding a more uniform product, as well as improving its appearance. When only sorting efficiency is under consideration, it can be expressed as the proportion of defects removed in relation to the percentage of defects in the incoming product (Malcolm \& DeGarmo, 1953).

Although some authors provide excellent analytical tools to measure sorting and/or sizing efficiencies (Peleg, 1985; Bollen et al., 1993) these are not easy to apply under our real conditions because they are only applicable in highly standardized operations, requiring complex calculations and feeding formulae with sometimes hardto-obtain information. Under Argentine conditions, the number of sorters/line, the product load per unit of time and speed of conveyors are highly variable, even within the same day, being highly correlated to the desired quality as well as to the percentage and type of defects in the incoming product, particular requirements of the buyer, expected sale price, urgency in loading trucks and sometimes weather, as onions are stored in the field. Moreover, sorters do not always know exactly what they are supposed to look for and training is not considered a priority.

The objective of this study was to find a simple and quick method to characterize efficiency in the sorting and sizing operations of onion packinghouses that could be used to monitor quality in Quality Assurance Programs.

\section{MATERIAL AND METHODS}

Five onion packinghouses located in the Valle Bonaerense del Río Colorado (Buenos Aires Province, Argentina) were selected at random and studied during the 1998 season. The operation of the sorting system was characterized by the following variables: table width, belt speed, bulb rotation speed and bulbs/sorter/hour. Based on previous sampling studies (López Camelo et al., 1998), samples of 100 bulbs were drawn before and after sorting for each size. As no difference in percentage of defects was found within sizes, data were pooled. Every single bulb was closely inspected and its cross section diameter was precisely measured with a hand caliper. Individual defects were identified and, according to the Mercosur specifications, grouped into three categories: Basic requirements, slight or severe defects (IASCAV 1995).

A Chi-square test was performed to compare observed frequencies of defects with the expected ones within each category. This test is very useful for the evaluation of discrete or categorical data (basic requirements, slight and severe defects, in this case). The smaller the value of $\chi^{2}$, the closer the agreement between expected and observed frequencies. Calculated $\chi^{2}$ exceeding tabulated values at the corresponding probability level, indicate a significant disagreement with expected figures. Mercosur tolerances were used as expected frequencies $(1 ; 2$ and 5 for Extra class and 1; 5 and 10\% for class 1, for basic requirements, severe and slight defects, respectively). Standards do not specify limits for basic requirements stating that all bulbs must meet these conditions ( $=0$ tolerance) . To avoid dividing by 0 yielding nonsense values, basic requirement tolerance was set equal to $1 . \mathrm{c}^{2}$ values were calculated by the following formula:

$$
\begin{gathered}
\chi^{2}=\left(\mathbf{O}_{B R}-\mathbf{E}_{B R}\right)^{2} * \mathbf{E}_{B R}^{-1}+\left(\mathbf{O}_{S D}-\mathbf{E}_{S D}\right)^{2} \\
* \mathbf{E}_{S D}^{-1}+\left(\mathbf{O}_{S d}-\mathbf{E}_{S d}\right)^{2} * \mathbf{E}_{S d}^{-1}
\end{gathered}
$$

Where: $\mathrm{O}=$ observed; $\mathrm{E}=$ expected; ${ }_{B R}=$ basic requirements; ${ }_{S D}=$ severe defects; ${ }_{S d}=$ slight defects.

Mean diameters and their standard deviations were calculated as well as the percentages of under- and oversized bulbs. The probability of an already sized single bulb, randomly taken, being within the specified size limits was also calculated by converting them to $\mathrm{z}$ values and referring them to a standard normal probability curve by the following formula.

\section{$\mathbf{P}(\mathbf{L} \leq \mathrm{Y} \leq \mathrm{H})=\mathrm{P}[(\mathrm{L}-\boldsymbol{\mu}) / \sigma] \leq \mathrm{Z} \leq[(\mathrm{H}-\boldsymbol{\mu}) / \sigma]$}

Where: $\mathrm{L}=$ Lower limit of the size category; $\mathrm{H}=$ Higher limit of the size category; $\mu=$ Mean diameter of the size category; $\sigma=$ Standard deviation of the size category; $Z=$ reference value to the standard normal probability curve.

\section{RESULTS AND DISCUSSION}

Basic operational parameters of the studied packinghouses indicated that three of them sized bulbs before sorting with very similar equipment and sorters located at one side of the sorting table. The remaining two packinghouses sorted before sizing with wider sorting tables and operators at both sides. One of them used diverging belts while the other used belts and rollers. Bulb 
Table 1. Operational parameters for five onion packinghouses studied in the Valle Bonaerense del Río Colorado, Argentina, INTA, 1998.

\begin{tabular}{cclcccc}
\hline $\begin{array}{c}\text { Packing- } \\
\text { house }\end{array}$ & $\begin{array}{c}\text { First } \\
\text { operation }\end{array}$ & \multicolumn{1}{c}{ Sizer } & $\begin{array}{c}\text { Sorter } \\
\text { position and } \\
\text { table width } \\
(\mathbf{m})\end{array}$ & $\begin{array}{c}\text { Sort table } \\
\text { speed } \\
(\mathbf{m} / \mathbf{m i n})\end{array}$ & Bulb rotation & $\begin{array}{c}\text { Bulbs/ } \\
\text { sorter/ } \\
\text { hour }\end{array}$ \\
\hline 1 & Sizing & Diverging rollers & $(1$ side) 0.40 & 7.35 & 2.5 & 10,800 \\
2 & Sizing & Diverging rollers & $(1$ side) 0.40 & 4.85 & 3.0 & 10,746 \\
3 & Sizing & Diverging rollers & $(1$ side) 0.33 & 8.89 & 3.0 & 10,656 \\
4 & Sorting & Diverging belts & $(2$ sides $) 0.85$ & 8.36 & 2.5 & 11,052 \\
5 & Sorting & Belt \& rollers & $(2$ sides $) 0.85$ & 7.18 & 2.5 & 12,060 \\
\hline
\end{tabular}

Table 2. Percentage of defects (in and outflow) and other efficiency parameters in the studied packinghouses in the Valle Bonaerense del Río Colorado, Argentina, INTA, 1998.

\begin{tabular}{ccccccc}
\hline \multirow{2}{*}{ Packinghouse } & $\begin{array}{c}\text { Defects } \\
\text { inflow }\end{array}$ & Removal & $\begin{array}{c}\text { Basic } \\
\text { requirements }\end{array}$ & $\begin{array}{c}\text { Severe } \\
\text { defects }\end{array}$ & $\begin{array}{c}\text { Slight } \\
\text { defects }\end{array}$ & $\begin{array}{c}\mathbf{2}_{\text {for extra }} \\
\text { class } \text { ( }^{*} \text { ) }\end{array}$ \\
\cline { 2 - 7 } (\%) & & \multicolumn{5}{c}{ \% defectives in the outflow } \\
\hline 1 & 34.3 & 17.0 & 3.0 & 3.3 & 11.0 & 12.1 \\
2 & 23.0 & 14.7 & 0.7 & 0.3 & 7.3 & 2.6 \\
3 & 33.0 & 12.4 & 2.3 & 1.7 & 16.7 & 29.0 \\
5 & 20.9 & 1.6 & 7.3 & 4.7 & 7.3 & 44.7 \\
5 & 34.7 & 11.0 & 2.0 & 4.0 & 17.7 & 35.1 \\
\hline
\end{tabular}

$(*) \chi^{2}$ values larger than the tabular one (5.99 for 2 degrees of freedom and at 5\% probability) indicate significant disagreement between observed and expected values

rotation speed was very similar in all the packinghouses and although $\mathrm{N}^{\circ} 4$ and 5 had a slightly higher throughput in terms of bulbs/sorter/hour, no major differences existed in their operational characteristics (Table 1).

Inflow product, as it came from the field, had a relatively high and variable percentage of defects and although packinghouses reduced them, defective units were not completely removed (Table 2). packinghouse 4 had the lowest removal proportion and the highest number of bulbs not meeting allowed percentages of both basic requirements and severe defects in the outflow. With exception of $\mathrm{N}^{\circ} 2$, the rest of the packinghouses failed to comply with standards for basic requirements, only $\mathrm{N}^{\circ} 2$ and $\mathrm{N}^{\circ} 3$ met the requirements for severe defects $(2 \%)$ and all of them exceeded limits for the slight ones (5\%). Results indicated that only $\mathrm{N}^{\circ} 2$ was meeting Extra class requirements, and was the most efficient in reducing those defects that standards penalize most. Calculated $\chi^{2}$ for Packinghouse 2 indicated that the disagreement was not significant between observed and expected (standard's limits for Extra class) values and differences were due to chance $(\alpha=0.05)$.

Calculated $\chi^{2}$ also suggests that sizing before sorting yielded a better product. On average, the first three packinghouses did a better job than the last two and several reasons could account for these differences, the sequence of operations and number of bulbs/sorter/hour probably being the most important ones (Table 1). It is well known that sorting already-sized products increases accuracy by reducing "noise" in the incoming product making easier to find defective units. Moreover, output in the first three packinghouses was close to the $9000 \mathrm{bulbs} / \mathrm{sorter} / \mathrm{hour}$ recommended by Bishop (1990) to obtain top quality onions. Lastly, even though sorters were staggered at both sides of the sorting table for packinghouses 4 and 5 , this system usually creates blind areas where the individual bulb would otherwise be checked from the other side of the table.

The better job in removing defective onion bulbs performed by packinghouse
2 could be in part attributable to bettertrained personnel, but probably the most important factor was the lower running speed of the sorting table conveyor belts (4.85 $\mathrm{m} \mathrm{min}^{-1}$ ). Similar number of bulbs/ sorter/hour with lower sort table belt speed means that sorters had a higher load per unit of time, but each individual bulb had about twice the time to be inspected within their inspection area (an oval area of about $50 \mathrm{~cm}$ long and sorting table width) than in the other situations. Other researchers (Prussia \& Meyers, 1989) also indicate the importance of belt speed to improve sorting performance.

All the studied packinghouses classified onions in three size categories, although limits of the size ranges varied between them and in some cases some overlapping existed. The probabilities of being correctly sized ( $\mathrm{z}$ test) ranged from 0.72 (packinghouse 5 , size range $40-50 \mathrm{~mm}$ ) to 0.94 (packinghouse 4 , size range $40-60 \mathrm{~mm}$ ) and the average range for all five packinghouses was 0.82 0.86 , meaning that, in general, all packinghouses sized bulbs within 
IASCAV tolerances. In this study, calculated probability also indicated that, on average, diverging roller systems did a better job than diverging belts and belts and boards, with the best job done in packinghouse 2 .

Although excellent analytical tools to measure sorting and/or sizing efficiencies are available, simple and easy-to-calculate indexes could be more useful and practical under real operational conditions where $6000-8000$ twenty five kilograms sacks per day are graded. Even with a similar throughput of bulbs/sorter/hour, packinghouses differed in their sorting and sizing performance. Design and operational parameters along with training of the personnel largely contribute to the improvement of the overall efficiency. Sizing before sorting and the running speed of sorting tables are probably the most important factors. Under our conditions, about $5 \mathrm{~m} / \mathrm{min}$ maximum seems to be the most appropriate when Extra class onions are desired. Based on easy calculations, the proposed methodology for characterizing efficiency could be considered as a simple and useful tool for monitoring quality at onion packinghouses.

\section{ACKNOWLEDGMENT}

We would like to thank Dr. Lesley Currah for critical reading and helpful suggestions during the preparation of the manuscript.

\section{CITED LITERATURE}

BISHOP, C.F. On-farm grading and cleaning of potatoes and onions-techniques and equipment to improve returns. Agricultural Engineer, v. 45, n. 2, p. 40-42. 1990.

BOLLEN, F.; PRUSSIA, S.E.; LIDROR, A. Visual inspection and sorting: Finding poor quality before the consumer does. In: SHEWFELT, R.L.; PRUSSIA, S.E. (eds.) Postharvest Handling. A System Approach. San Diego, California, Academic Press, 1993. p. 197-209.

IASCAV (Instituto Argentino de Sanidad y Calidad Vegetal). Reglamento Técnico del Mercado Común del Sur (MERCOSUR) para la fijación de identidad y calidad de cebolla. Expediente 1034/95. Resolución IASCAV n ${ }^{\circ} 88 /$ 95. 1995.
LIDROR, A. Human factors principles for agricultural quality control. ASAE Paper n. 891116. 1989.

LIDROR, A.; PRUSSIA, S.E. Improving quality assurance techniques for producing and handling agricultural crops. Journal of Food Quality, v. 13, p. 171-184, 1990.

LOPEZ CAMELO, A.; GOMEZ, P.; HORVITZ, S.; AZPILICUETA, A. La aplicación del HACCP en un sistema de aseguramiento de la calidad para la cebolla de exportación. Proceedings of the XXI Argentine Congress in Vegetable Crops. San Pedro, Argentina. 1998.

MALCOLM, D.G.; DEGARMO, E.D. Visual inspection of products for surface characteristics in grading operations. USDA Marketing Research Report, n. 45. 1953.

PELEG, K. Sorting operations. In: PELEG, K (ed.) Produce Handling, Packaging and Distribution. Chapter 5, pp. 53-87. AVI Publishing Co., Inc. Westport, Connecticut, USA. 1985.

PRUSSIA, S.E. Visual sorting at ergonomically designed workstations. ASAE Paper n. 85-1618. 1985.

PRUSSIA, S.E. and J.B. MEYERS Jr. 1989. Ergonomics for improving visual inspection at fruit packinghouses. Acta Horticulturae, n. 258, p. 357-364.

SAGPyA (Secretaría de Agricultura, Ganadería, Pesca y Alimentación de Argentina). Homepage: http://www.siiap.sagyp.mecon.ar/. Consulted on 1999. 